fjernmetastaser er hjernen, og hjernemetastaser forekommer hos opptil $40 \%$ under eller etter gjennomgått behandling (11). Utredningen bør derfor inkludere MR caput $i$ tillegg til MR-undersøkelse av tumorområdet både før og etter kjemoradioterapi for preoperativ vurdering av tumorutbredelse.

Behandling av lungekreft representerer en utfordring, idet man knapt har sett bedret overlevelse de siste 40 årene, til tross for bedre diagnostikk, mer avanserte kirurgiske teknikker og strålebehandling. Pancoastsvulster kan ubehandlet gi et stort smerteproblem pga. lokal innvekst i nerver og andre strukturer. Det er derfor grunn til å behandle aggressivt, selv der kun pallativ behandling er indisert. Dersom man ikke oppnår tilfredsstillende smertelindring med multimodal eller konvensjonell palliativ behandling, kan cervikal kordotomi vurderes (12).

Studier publisert i 1960-årene påviste en viss bedring i resultater hos Pancoast-pasienter som fikk strålebehandling etterfulgt av kirurgisk reseksjon (13). De siste årene har flere rapporter pekt på at cellegiftbehandling gitt sammen med strålebehandling før operasjon øker sannsynligheten for komplett patologisk respons og bedret overlevelse uten uakseptable bivirkninger (6). Man kan dermed ha mulighet for kurasjon på tross av avansert sykdom.

Det er i regi av Norsk lungekreftgruppe planlagt en fase 2-studie som tilsvarer behandlingsopplegget denne pasienten mottok. Selv om det gjenstår flere spørsmål når det gjelder stråledosering, cellegifttype og -dosering, vil implementering av multimodal behandling i Norge forhåpentlig bidra til bedret overlevelse for denne pasientgruppen.

\section{Camilla M.T. Sagerup}

camsa@radiumhospitalet.no

Odd Terje Brustugun

Kreftklinikken

Oslo universitetssykehus, Radiumhospitalet 0310 Oslo

\section{Lars Jørgensen}

Kirurgisk avdeling

Oslo universitetssykehus, Rikshospitalet

Pasienten har gitt samtykke til at artikkelen blir publisert.

\section{Oppgitte interessekonflikter: Ingen}

\section{Litteratur}

1. Sanders RJ, Hammond SL, Rao NM. Diagnosis of thoracic outlet syndrome. J Vasc Surg 2007; 46 601-4.

2. Arcasoy SM, Jett JR. Superior pulmonary sulcus tumors and Pancoast's syndrome. N Engl J Med 1997: 337: $1370-6$

3. Narayan S, Thomas CR jr. Multimodality therapy for Pancoast tumor. Nat Clin Pract Oncol 2006; 3 : 484-91.

4. Rusch VW. Management of Pancoast tumours Lancet Oncol 2006; 7: 997-1005.
5. Webb WR Gatsonis C. Zerhouni EA et al. CT and MR imaging in staging non-small cell bronchogenic carcinoma: report of the Radiologic Diagnostic Oncology Group. Radiology 1991; 178: 705-13.

6. Rusch VW, Giroux DJ, Kraut MJ et al. Induction chemoradiation and surgical resection for super ior sulcus non-small-cell lung carcinomas: long term results of Southwest Oncology Group Trial 9416 (Intergroup Trial 0160). J Clin Oncol 2007; 25 313-8

7. Rusch VW, Giroux DJ, Kraut MJ et al. Induction chemoradiation and surgical resection for nonsmall cell lung carcinomas of the superior sulcus: initial results of Southwest Oncology Group Trial 9416 (Intergroup Trial 0160). J Thorac Cardiovasc Surg 2001; 121: 472-83

8. MacManus M, Hicks RJ. The use of positron emission tomography (PET) in the staging/evaluation. treatment, and follow-up of patients with lung cancer: a critical review. Int J Radiat Oncol Biol Phys 2008; 72: 1298-306.

9. Pancoast H. Superior pulmonary sulcus tumor: tumor characterized by pain, Horner's syndrome. destruction of bone and atrophy of hand muscles. JAMA 1932; 99: 1391-6

10. Attar S, Krasna MJ, Sonett JR et al. Superior sulcus (Pancoast) tumor: experience with 105 patients. Ann Thorac Surg 1998; 66: 193-8.

11. Shah H, Anker CJ, Bogart J et al. Brain: the common site of relapse in patients with pancoast or superior sulcus tumors. J Thorac Oncol 2006; 1 : $1020-2$

12. Rosomoff HL, Brown CJ, Sheptak P. Percutaneous radiofrequency cervical cordotomy: technique. J Neurosurg 1965; 23: 639-44.

13. Shahian DM. Contemporary management of superior pulmonary sulcus (Pancoast) lung tumors. Curr Opin Pulm Med 2003; 9: 327-31.

Manuskriptet ble mottatt 3.3. 2009 og godkjent 16.9. 2009. Medisinsk redaktør Anne Kveim Lie.

\title{
Sjeldne tilstander er sjeldne
}

«Sjeldne tilstander er sjeldne,» pleide

min allmennpraktikerkollega å si. Før han fortsatte: «Men det er veldig mange av dem.» Han likte å imponere studentene som var utplassert hos oss med å vise frem pasienter med Fallots tetrade (3-6 per 10000 fødsler) (1), Marfans syndrom (prevalens $0,02 \%$ ) (1) eller medfødt diafragmabrokk (1 per 3 000-4 000 fødsler, svarende til én hvert 100. år i min praksispopulasjon) (2). Studentene smilte høflig, men forbeholdent. Sjeldne sykdommer hadde de sett på Rikshospitalet, nå var de i allmennpraksis for å lære om de alminnelige.

Klinisk diagnostikk innebærer å tolke hvert trinn i den diagnostiske prosessen: sykehistorien, den fysiske undersøkelsen samt ulike prøvesvar. Hvor mye resultatet av hvert av disse trinnene endrer sannsynligheten for at pasienten har en gitt sykdom (posttestsannsynlighet), avhenger sterkt av den antatte prevalensen av sykdommen i den gitte populasjon (pretestsannsynlighet) (3). I allmennpraksis er pasientpopulasjonen lav- prevalent for alle alvorlige sykdommer, og det store flertall av de helseproblemene som presenteres for legen er uskyldige og/eller selvbegrensende. I startfasen av en alvorlig sykdom er symptomene dessuten ofte identiske med plagene ved de mindre alvorlige. Pasienten som er beskrevet i kasuistikken, hadde hatt perioder med smerter i brystveggen gjennom 20 år. De foregående tre månedene hadde han vært plaget av smerter $i$ høyre skulderblad, beskrevet som «tusen knivstikk i armen», i tillegg til en prikkende følelse. Dette viste seg altså å skyldes en Pancoast-tumor - en malign svulst i høyre lungetopp.

«Fordi skuldersmerter er et av de mest typiske symptomene (ved Pancoast-tumor), blir mange initialt behandlet for antatte muskel-skjelett-plager, og symptomene kan vedvare $\mathrm{i}$ måneder før videre utredning igangsettes,» skriver forfatterne. En japansk undersøkelse av 48 pasienter med Pancoasttumor viste at det gikk i gjennomsnitt 164 dager fra symptomdebut til behandlingsstart
(38-400 dager) (4). En tredel av «forsinkelsen» skyldtes at pasientene ikke søkte lege før etter en tid, to tredeler (14 til 349 dager) at legene brukte tid på å stille diagnosen - i alle ledd av utredningskjeden.

Til tross for omfattende søk har jeg ikke klart å finne opplysninger om hvor ofte Pancoast-tumor forekommer, men den beskrives som sjelden. Problemer i nakke, skulder og arm er derimot i en norsk undersøkelse angitt å stå for $7 \%$ av konsultasjonene i allmennpraksis (5), hvilket for mitt vedkommende betyr ca. 240 pasientkontakter i året. Skal jeg så begynne å tenke på at disse kan ha en Pancoast-tumor og utrede med tanke på dette? Nei, selvsagt ikke. Myalgier, tendinitter og bursitter skal fortsatt være fremst i bevisstheten.

Men - som min kollega så riktig sa - det er mange av de sjeldne tilstandene. Så hvordan skal vi klare å fange dem opp blant alle trivialitetene? Jeg tror allmennleger ofte kommer på sporet av alvorlige tilstander ved at vi får et inntrykk av at «her er det noe som 
ikke stemmer». Med årene får vi mengdetrening når det gjelder de vanlige sykdommene - og så en dag ser vi noe som avviker. Pasienten i kasuistikken ble faktisk innlagt i sykehus grunnet smerter $\mathrm{i}$ thoraxveggen som han hadde hatt $i$ perioder gjennom 20 år. Hva var det legen hadde oppfattet som annerledes enn tidligere og som gjorde at han la pasienten inn? Vi skal tillate oss å ta vår kliniske intuisjon alvorlig (6). Og vi må ikke glemme å undersøke pasienten selv om sykehistorien peker i retning av noe banalt. Dessuten bør vi være ydmyke nok til ikke å kommunisere skråsikkerhet overfor pasienten, men holde muligheten åpen for ny kontakt og ny vurdering hvis forløpet skulle avvike fra det antatte.

\section{Mette Brekke}

mette.brekke@medisin.uio.no

Institutt for allmenn- og samfunnsmedisin

Universitetet i Oslo

Postboks 1130 Blindern

0318 Oslo

\section{Oppgitte interessekonflikter: Ingen}

\section{Litteratur}

1. www.legehandboka.no NEL Online (26.8.2009)

2. Skari H, Bjørnland K, Haugen $G$ et al. Congenital diaphragmatic hernia: a meta-analysis of mortality factors. J Pediatr Surg 2000; 35: 1187-97.

3. Gill CJ, Sabin L, Schmid CH. Why clinicians are natural Bayesians. BMJ 2005; 330: 1080-3.

4. Ichinohe K, Takahashi M, Tooyama N. Delay by patients and doctors in treatment of Pancoast tumor. Wien Klin Wochenschr 2006; 118: 405-10.

5. Grimsmo A, Grimstad SA, Lilleholdt 0 et al. Informasjon til kvalitetssikring og selvevaluering i allmennpraksis. Bruk av data fra EDB-journalen i allmennpraksis. Tidsskr Nor Legeforen 1994; 114: 1983-7.

6. Skarsaune K. La reven leve! Om intuisjonens plass i allmennmedisinen. Utposten 1991; 20: 289-91.

Manuskriptet ble mottatt 3.9. 2009 og godkjent 15.10. 2009. Medisinsk redaktør Anne Kveim Lie. 